\title{
Screening and Molecular Identification of New Microbial Strains for Production of Enzymes of Biotechnological Interest
}

\author{
Imen Ghazala ${ }^{1}$, Anissa Haddar ${ }^{\mathbf{*}}$, Molka Ben Romdhane ${ }^{\mathbf{1}}$, Semia Ellouz-Chaanouni ${ }^{1}$. \\ ${ }^{1}$ Escole Nationale d’'Ingenieurs de Sfax, Sfax, Tunisia.
}

\begin{abstract}
This research focused on isolation, identification and characterization of new strains of fungi and bacteria, which were able to produce extracellular xylanase, mannanase, pectinase and $\alpha$-amylase. Fungi isolates were identified on the basis of analyses of $18 S$ gene sequencing and internal transcribed spacer region. The closest phylogenetic neighbors according to $18 S$ gene sequence and ITS region data for the two isolates MI and SE were Aspergillus fumigatus and Aspergillus sydowii, respectively. I4 was identified as Bacillus mojavensis on the basis of the 16S rRNA gene sequencing and biochemical properties. The enzyme production was evaluated by cultivating the isolated microorganisms in liquid-state bioprocess using wheat bran as carbon source. Two fungi (M1, and SE) and one bacterium (I4) strains were found to be xylanase producer, and several were proven to be outstanding producers of microbial xylanase. The strains producing xylanase secreted variable amounts of starch-debranching enzymes and produced low level $\beta$-mannan-degrading enzyme systems. The bacterium strain was found to be capable of producing pectinolytic enzymes on wheat bran at high level. Some of the strains have good potential for use as sources of important industrial enzymes.
\end{abstract}

Key words: Xylanase; pectinase, $\beta$-mannanase; $\alpha$-amylase; Bacillus mojavensis, Aspergillus fumigatus and Aspergillus sydowii.

${ }^{1}$ Authors for correspondence: anissa_ing@yahoo.fr 


\section{INTRODUCTION}

Microbial enzymes are routinely used in many environment friendly and economic industrial sectors (Hoondal et al. 2002). Microbes are the best source of enzymes as they allow an economical technology with low resource consumption and low emission involving no social and political issues, as in the case of animal and plant sources (Dalvi and Anthappan 2007). Such enzymes may be discovered by screening microorganisms sampled from diverse environments or developed by modification of known enzymes using modern methods of protein engineering or molecular evolution. New enzymes for commercial applications with desirable biochemical and physico-chemical characteristics and a low cost production have become a focus of research (Malvessi and Silveira 2004; Phutela et al. 2005).

Microbial xylanases have attracted great attention due to their biotechnological uses and potential application in various industrial processes, such as bioconversion of lignocelluloses material to fermentative products, clarification of juices, improvement of the consistency of beer and the digestibility of animal feed stock (Butt et al. 2008), and production of acidic xylooligosaccharides having potential pharmacological benefits (Christakopoulos et al. 2003). Kumar and Satyanarayana (2012) reported that the hydrolysis of xylan facilitates the release of lignin from paper pulp and reduces the use of chlorine as bleaching agent. The use of enzymes, other than xylanase and ligninase, such as mannanase, pectinase and galactosidase is increasing in the paper and pulp industries in several countries (Virk et al. 2013). The enzyme aided bleaching reduces the requirement of bleaching chemicals to attain the same extent of brightness and enhanced physical properties.

$\beta$-mannanase, known as hemicellulases, is widely distributed among bacteria, fungi, plant, and marine mollusks (Zahura et al. 2010). $\beta$-Mannanases have a wide range of potential industrial applications. They are used in combination with xylanases in the paper and pulp industries for increasing the brightness of pulps and in the detergent industry (Moreira and Filho 2008). The paper and pulp and detergent industries have therefore focused on the use of bacterial $\beta$-mannanases with high activity at elevated $\mathrm{pH}$ levels in these applications, many of which have been isolated from Bacillus spp. Many strains of Bacilli produce enzymes that are tolerant of alkaline $\mathrm{pHs}$ and high temperatures, thus making them very useful in applications such as detergents (Schallmey and Singh 2004). They estimated that commercial enzymes from Bacillus spp. make up about $50 \%$ of the enzyme market. Bacillus licheniformis specifically, is used to produce a commercial alkaline serine protease and an $\alpha$ amylase that is able to operate at $95^{\circ} \mathrm{C}$ as well as withstand temperatures of $105-110^{\circ} \mathrm{C}$ for short periods (Schallmey and Singh 2004). $\alpha$-amylases are the second important enzymes after proteases used in detergent industries. These enzymes catalyze the hydrolysis of glucosidic linkages in starch polymers, commonly found in foods such as pasta, fruit, chocolate, baby food, barbecue sauce and gravy. As coloured stains, their removal is of interest in both detergent and dishwashing contexts. Removal of starch from surfaces is also important in providing a whiteness benefit, since it is known that starch can be an attractant for many types of particulate soils. The most common class of detergent $\alpha$-amylases are the $\alpha$-amylases, which hydrolyze the 1,4- $\alpha$-glucosidic bonds in starch. Most commercial $\alpha$-amylases are derived from either the Bacillus or Aspergillus genera (Hmidet et al. 2009).

Pectinase is also a well known term for commercial enzyme preparation that break down pectin; a polysaccharide substrate, found in the plants cell wall (Oyewole et al. 2011). This enzyme splits polygalacturonic acid into monogalacturonic acid by opening glycosidic linkages. Through this process, it softens the cell wall and increase the yield of juice extract from fruits. The two major sources of pectinase are plant and microorganism. But for both technical and economic point of view microbial source of pectinase has become increasingly important. A great variety of strains of bacteria, yeast and mold are capable to produce pectic enzymes. The composition of pectic enzymes varies among species of microorganisms (Oyewole et al. 2011). Many studies have been reported that the enzyme preparations used in the food industry are of fungal origin because fungi are the potent producers of pectic enzymes (Abe et al. 1988). Today, pectinases are of great significance in the food and textile industries (Ortega et al. 2004), saccharification of food residues (Zhang et al. 2010), as well as in the pulp and paper industry (Ricard and Reid 2004). In the hydrolysis of grape fruit peel waste, the pectinase preparation used was found to be more effective than the cellulase preparation, obviously due to the wider spectrum of 
activities in the pectinase preparation (Wilkins et al. 2007).

Considering the industrial importance of enzymes, in this present study, bacteria and fungi were isolated from soil and screened for xylanase, mannanase, pectinase and $\alpha$-amylase production. The results of an extensive screening for the production industrially important polysaccharide hydrolases are presented.

\section{MATERIALS AND METHODS}

\section{Chemicals}

Citrus pectin, oat spelt xylan, galactomannan from Ceratonia siliqua (Locust Bean Gum: LBG) and starch were obtained from Sigma. Carbon source used for the enzyme production was wheat bran (provided by the Tunisian Society for Food Production STPA, Sfax).

\section{Bacteria isolation}

For primary screening, $1 \mathrm{~g}$ of soil sample were suspended in $10 \mathrm{ml}$ of sterile saline $(9 \mathrm{~g} / \mathrm{l} \mathrm{NaCl})$, mixed uniformly, and allowed to settle then $100 \mu \mathrm{l}$ aliquot of clear suspension of soil sample was plated onto nutrient-agar wheat bran medium, $\mathrm{pH} 8$ containing (g/l): $\mathrm{NaCl} 5$, yeast extract 2, Agar 15 and wheat bran 10. Plates were incubated for $24 \mathrm{~h}$ at $45^{\circ} \mathrm{C}$ and the obtained colonies were further transplanted onto fresh nutrient agar-oat spelt xylan plates $0.2 \%(\mathrm{w} / \mathrm{v})$, agar-LBG plate $0.5 \%(\mathrm{w} / \mathrm{v})$, agar-pectin plate $1 \%(\mathrm{w} / \mathrm{v})$ and agar-starch plate $1 \%$ $(\mathrm{w} / \mathrm{v})$. After $24 \mathrm{~h}$ incubation at $45^{\circ} \mathrm{C}$, xylanase, mannanase and pectinase producing strains were selected by flooding replica plates in $0.2 \%(\mathrm{w} / \mathrm{v})$ Congo red for 15 min followed by several wash with $1 \mathrm{M} \mathrm{NaCl}$ for zone analysis (Gessesse and Gashe 1997). Concerning $\alpha$-amylase activity, the plate was flooded in iodine reagent ( $2 \%$ iodine in $0.2 \%$ potassium iodine).

\section{Fungus isolation}

Five milliliter of effluent, sampled from pasta and semolina Industry (DIARI, Sfax Tunisia), were resuspended in $25 \mathrm{ml}$ of sterile $1 \%(\mathrm{w} / \mathrm{v})$ wheat bran, and enriched by incubation in shaking incubator for $72 \mathrm{~h}$ at $30{ }^{\circ} \mathrm{C}$ and $150 \mathrm{rpm} .100 \mu \mathrm{l}$ of enriched culture was plated onto potato dextrose agar (PDA) media and incubated for 3 days at 30 ${ }^{\circ} \mathrm{C}$. Fungi isolated were spotted onto agar medium, pH 5.5 containing $(\mathrm{g} / \mathrm{l}):\left(\mathrm{NH}_{4}\right)_{2} \mathrm{SO}_{4}: 1.4 ; \mathrm{MgSO}_{4}$ : 0.3; $\mathrm{KH}_{2} \mathrm{PO}_{4}: 2 ; \mathrm{CaCl}_{2}: 0.3 ; \mathrm{NaNO}_{3}$ : 5; Tween 80: $1 \mathrm{ml} / \mathrm{l}$ and 15.0 agar. The carbon source was oat spelt xylan (0.2\%), LBG (0.5\%), citrus pectin (1\%) or starch $(1 \%)$. Xylanase, mannanase, pectinase and $\alpha$-amylase were evidenced as described for bacteria isolation.

\section{Identification of the selected isolates}

To identify the species of the isolates, genomic DNA was extracted and purified by using the Wisard Genomic DNA purification kit (Promega) following the manufacturer instruction, and its purity was assessed by agarose gel electrophoresis. The 16S rDNA gene fragment was amplified using FD1:5'-AGAGTTTGATCCTGGCTCAG-3'

(Forward) and RD1: 5'AAGGAGGTGATCCAAGCC-3' (Reverse) which generated a DNA fragment of approximately 1.5 $\mathrm{kb}$. The PCR mixture contained : gDNA (20 ng), corresponding PCR primers $(1 \mu \mathrm{M}$ each), $5 \mu \mathrm{l}$ of 10x Taq buffer, $\mathrm{MgCl}_{2}(1.5 \mathrm{mM})$, dNTP $(0.2 \mathrm{mM}$ each), $0.25 \mu 1$ of GoTaq $^{\circledR}$ Flexi DNA Polymerase (Promega) in a final volume of $50 \mu$ l. PCR thermal cycling was carried out as follows: an initial denaturing step at $95{ }^{\circ} \mathrm{C}$ for $5 \mathrm{~min}, 30$ cycles of 94 ${ }^{\circ} \mathrm{C}$ for $1 \mathrm{~min}, 60^{\circ} \mathrm{C}$ for $1 \mathrm{~min}$ and $72{ }^{\circ} \mathrm{C}$ for $2 \mathrm{~min}$. For fungi identification, the $18 \mathrm{~S}$ rDNA and the THEIR regions were submitted to PCR amplification using fungus-specific primers, namely 18D: 5'- CCTGGTTGATCCTGCCAGTA3', 18R: 5'-GCTTGATCCTTCTGCAGGTT-3', ITS1: 5'-TCCGTAGGTGAACCTGCG-3' and ITS4: 5'-TCCTCCGCTTATTGATATG-3'. These generated a DNA fragment of approximately $1.8 \mathrm{~kb}$ and $0.65 \mathrm{~kb}$, respectively. The $18 \mathrm{~S}$ rDNA and the ITS1 region were amplified as described elsewhere (Verweij et al., 1995; White et al., 1990). PCR amplification was performed under the following conditions: initial denaturation at $95{ }^{\circ} \mathrm{C}$ for $5 \mathrm{~min}$, 35 cycles of $94{ }^{\circ} \mathrm{C}$ for $1 \mathrm{~min}, 52{ }^{\circ} \mathrm{C}$ for 30 s and 72 ${ }^{\circ} \mathrm{C}$ for 90 s and a final extension at $72{ }^{\circ} \mathrm{C}$ for $10 \mathrm{~min}$. PCR products were visualized by electrophoresis in $1 \%(\mathrm{w} / \mathrm{v})$ agarose gel stained by ethidium bromide and purified using the PureLink PCR Purification Kit (Invitrogen) following the manufacturer instruction. The purified PCR product was sequenced in both directions with the ABI PRISM BigDye Terminator Cycle Sequencing Ready Reaction Kit and the automated ABI Prism1 3100Avant Genetic Analyser (Applied Biosystems). Sequences for 16S, 18S rDNA and ITS region were compared with the sequences available in public database National Center for Biotechnology Information (NCBI). Based on the BLAST results sequences for other species were retrieved. All 
sequences were aligned using Clustal $\mathrm{W}$ and the phylogenetic tree was constructed and edited using Molecular Evolutionary Genetics Analysis version 5 (Tamura et al. 2011). Genetic relationships were inferred from neighbor-joining nucleotide alignment after 1000 bootstrap replicates using the Tajima-Nei model.

\section{Culture conditions}

Two fungal isolates were screened for xylanase, mannanase, pectinase and $\alpha$-amylase production in Erlenmeyer flasks $(500 \mathrm{ml})$ containing $100 \mathrm{ml}$ of basal medium of Mandels et al. (1976) buffered to pH 5.5 (g/l): $\left(\mathrm{NH}_{4}\right)_{2} \mathrm{SO}_{4}: 1.4 ; \mathrm{MgSO}_{4}: 0.3 ; \mathrm{KH}_{2} \mathrm{PO}_{4}$ : 2; $\mathrm{CaCl}_{2}: 0.3 ; \mathrm{NaNO}_{3}: 5$; Tween 80 and trace element solution ( $\mathrm{g} / \mathrm{l} \mathrm{CoCl}_{2}: 2 ; \mathrm{MnSO}_{4} \mathrm{H}_{2} \mathrm{O}$ : 1.6; $\mathrm{ZnSO}_{4} \mathrm{H}_{2} \mathrm{O}: 1.4 ; \mathrm{FeSO}_{4} 7 \mathrm{H}_{2} \mathrm{O}: 0.5$ ) were added at $1 \mathrm{ml} / \mathrm{l}$. The carbon source was $1 \%(\mathrm{w} / \mathrm{v})$ of wheat bran. Fresh fungal spores have been used as inocula, and the flasks were incubated at $30^{\circ} \mathrm{C}$ for 5 days in a rotary shaker $(150 \mathrm{rpm})$. After the growth step, the culture supernatant was separated from the mycelium by centrifugation at $8000 \mathrm{rpm}$ for $30 \mathrm{~min}$, filtered, through a filter paper (Whatman No. 4) and stored at $4^{\circ} \mathrm{C}$. The supernatant filtrate for each fungal strain was used as enzymes source.

One bacteria isolate was screened for the same activities as for fungi. Culture was carried in Erlenmeyer flasks $(250 \mathrm{ml})$ containing $25 \mathrm{ml}$ of basal culture medium $\mathrm{pH} 8.0$ containing (g/l); 10.0, wheat bran; 2.0, yeast extract; 5.0 $\mathrm{NaCl}$. Inocula were routinely grown in Luria-Bertani (LB) broth (Miller 1972). The culture was performed on a rotatory shaker $(150 \mathrm{rpm})$ for $24 \mathrm{~h}$ at $45^{\circ} \mathrm{C}$ and then centrifuged for $15 \mathrm{~min}$ at $10,000 \mathrm{rpm}$ and the cellfree supernatant was used for estimation of activity.

\section{Enzymatic Assays}

Xylanase activity was determined as described by Bailey et al. (1992) using 1\% (w/v) oat spelt xylan in $50 \mathrm{mM}$ sodium acetate buffer $\mathrm{pH} 5.5$ as substrate. The substrate and the enzyme appropriate dilution mixture was incubated at $50{ }^{\circ} \mathrm{C}$ for $30 \mathrm{~min}$, then 3 $\mathrm{ml}$ of dinitrosalicylate reagent was added to the solution. After boiling for $10 \mathrm{~min}$ and rapid cooling, the absorbance was determined at $550 \mathrm{~nm}$ (Miller 1959). The released reducing sugars were quantified using a xylose standard curve as a reference. One unit of enzyme activity was defined as the amount of enzyme required to produce 1 $\mu$ mol of xylose per min under assay conditions.

Mannanase, $\alpha$-amylase and pectinase activities were assayed as for xylanase by using $0.5 \%(w / v)$ of LBG, $1 \%(\mathrm{w} / \mathrm{v})$ starch and $1 \%(\mathrm{w} / \mathrm{v})$ citrus pectin as substrate respectively. For reducing sugars determination a mannose, glucose and galacturonic acid standard curve was used for each activity, respectively. One unit of enzymatic activity is defined as the amount of enzyme releasing $1 \mu \mathrm{mol}$ of corresponding reducing sugar per milliliter per minute under the described assay conditions. Results given are the mean of triplicate experiments.

\section{Protein measurement}

Protein concentration was measured by the method of Bradford (1976). Bovine serum albumin was used as a standard.

\section{Total soluble carbohydrates assay}

Soluble carbohydrates in crude extract were determined by the phenol-sulfuric acid method according to Dubois et al. (1956), using D-glucose as standard. For the assay, $1 \mathrm{ml}$ of $5 \%(\mathrm{w} / \mathrm{v})$ phenol solution and $5 \mathrm{ml} \mathrm{96 \%} \mathrm{H}_{2} \mathrm{SO}_{4}$ were added to $1 \mathrm{ml}$ of an appropriate dilution of the supernatant. Samples were incubated at room temperature for 20 min. The absorbance of each sample was spectrophotometrically determined at $490 \mathrm{~nm}$. Soluble carbohydrates content was expressed as $\mathrm{mg}$ per ml of substrate.

\section{Zymography}

Native PAGE electrophoresis was carried out at 4 ${ }^{\circ} \mathrm{C}$ using TBE buffer (89 mM Tris, 2 mM EDTA and $89 \mathrm{mM}$ boric acid) then it was stained for protein with Coomassie Brilliant Blue G250 (Laemmli 1970). A replicate gel containing 0.2\% oat spelt xylan, $0.5 \%$ LBG, $1 \%$ citrus pectin or $1 \%$ starch was incubated for $30 \mathrm{~min}$ at $50^{\circ} \mathrm{C}$ to detect xylanase, mannanase, pectinase or $\alpha$-amylase activity, respectively. After incubation, for visualizing pectinase, the gel was stained with Ruthenium red $(0.03 \%)$, and the bands of pectinase activity appeared as clear areas in a red gel background. In the case of xylanase and mannanase, the gels were stained with Congo red $(0.1 \%)$ for $10-15 \mathrm{~min}$ and destained by washing in $50 \mathrm{ml} 1 \mathrm{M} \mathrm{NaCl}$ until the xylanase and mannanase bands became obvious as clear zones where the xylane and LBG had been degraded due to enzymatic activity. After $20 \mathrm{~min}$, the gel was destained in a $5 \%(\mathrm{v} / \mathrm{v})$ acetic acid solution (Waeonukul et al. 2007). $\alpha$-amylase activity staining was performed by layering the gel on a thin starch gel containing agarose $(2 \%, \mathrm{w} / \mathrm{v})$ and soluble 
potato starch $(1 \%, w / v)$ and incubating the sandwich for $1 \mathrm{~h}$ at $50{ }^{\circ} \mathrm{C}$. Upon staining the agarose gel with iodine solution at room temperature, protein bands with amylolytic activity became visible as white bands against a dark blue background (Hmidet et al. 2009).

\section{Characterization of xylanase, pectinase, mannanase and $\alpha$-amylase activities for optimum $\mathrm{pH}$ and temperature}

The optimal $\mathrm{pH}$ of the xylanase, pectinase, mannanase and $\alpha$-amylase was studied over a $\mathrm{pH}$ range of $2.0-11.0$ at $50{ }^{\circ} \mathrm{C}$ with $1 \%$ xylan, $1 \%$ citrus pectin, $0.5 \% \mathrm{LBG}$ and $1 \%$ starch, respectively. The following buffer systems were used: $50 \mathrm{mM}$ glycine- $\mathrm{HCl}, \mathrm{pH} 2.0-4.0 ; 50 \mathrm{mM}$ sodium acetate buffer, $\mathrm{pH} 5.0-6.0 ; 50 \mathrm{mM}$ phosphate buffer, $\mathrm{pH}$ 7.0; $50 \mathrm{mM}$ Tris- $\mathrm{HCl}$ buffer, $\mathrm{pH} 8.0$ and $50 \mathrm{mM}$ glycine- $\mathrm{NaOH}$ buffer, $\mathrm{pH}$ 9.0-11.0.

To investigate the effect of temperature, enzyme activities were tested at different temperatures between 30 and $80{ }^{\circ} \mathrm{C}$ at the optimum $\mathrm{pH}$ of each enzyme.

\section{RESULTS AND DISCUSSION}

\section{Screening of glycosyl hydrolases producing fungus and bacteria}

Ten fungal and ten bacteria isolated from soil samples collected from different areas of Sfax Tunisia, were evaluated for xylanase, mannanase, pectinase and $\alpha$-amylase production. These isolates were purified by frequently restreaking on agar plate and subjected to preliminary screening by agar plate method on fresh nutrient agar-oat spelt xylan,
agar-LBG, agar-pectin and agar-starch for xylanase, mannanase, pectinase and $\alpha$-amylase production, respectively. The isolates which produce higher zone clearance are selected. Indeed, from 20 isolates, two fungi (M1 and SE) and one bacterium (I4) strains were selected for further study based on the prominence of zone of clearance on agarified plates (Table 1). In primary screening, formation of a clear zone around the colonies, after Congo red staining of nutrient agar medium containing xylan, indicated the colonies which were the xylanase producers. The use of commercial xylan containing nutrient agar plates for the screening of xylanase producing strains through the formation of zone of substrate hydrolysis have been reported by several works (Gupta et al. 2009; Nair et al. 2008; Yasinok et al. 2008). In a secondary screening, colonies of different isolates showing zone of clearance on pectin-nutrient agar medium were specified to be the pectinase microorganisms. The majority of researchers have assayed the pectinase activity qualitatively by spotting the isolates on pectin containing culture plates and then analyzing the pectin digestion zone (Mellon and Cotty 2004). The spotting of these xylanopectinolytic isolates on nutrient-agar medium containing LBG gave a zone of hydrolysis. In the final screening, when these isolates were transferred onto nutrient-agar medium containing starch, colonies forming a clear zone were indicated to be the $\alpha$-amylase producers. In addition to qualitative determinations, the results were confirmed by performing quantitative enzyme assays for all the isolates.

Table 1. Zone diameter ( $\mathrm{mm}$ ) of substrate hydrolysis of strain isolates

\begin{tabular}{lcccc}
\hline \multicolumn{4}{c}{ Hydrolysis zone diameter $(\mathrm{mm})$} \\
\hline Strains & Agar-oat spelt & Agar-pectin & Agar-LBG & Agar-starch \\
\hline M1 & $18 \pm 0.3$ & $20 \pm 0.1$ & $10 \pm 0.4$ & $15 \pm 0.1$ \\
SE & $17 \pm 0.15$ & $21 \pm 0.3$ & $12 \pm 0.5$ & $19 \pm 0.2$ \\
I4 & $20 \pm 0.2$ & $19 \pm 0.2$ & $17 \pm 0.15$ & $20 \pm 0.2$ \\
\hline
\end{tabular}

One of the major problems in screening large number of microbial strains for their glycosyl hydrolases producing ability is the lack of simple and fast reliable screening technique. Hence, solid agar screening method was used for screening and confirmed the enzyme production under submerged conditions by using the standard procedures. This technique, although useful, has its limitations. For example, Tseng et al. (2000) have found that, some of the strains previously identified as potential enzyme producing microbes on solid screening methods, did not produce any enzyme in liquid broth. In contrast, some strains, which were identified as negative, were shown to produce high 
amounts of enzyme (Tseng et al. 2000). Therefore, in order to rule out the omission of any isolate due to experimental limitation, all the isolates were cultured in liquid culture systems for enzyme production.

\section{Glycosyl enzyme production under submerged fermentation}

To evaluate their glycosyl enzyme production potential, the isolated microorganisms were grown in wheat bran, and the supernatants obtained from the fermentation process were evaluated to determine their xylanase, pectinase, mannanase and $\alpha$-amylase activities (Table 2). B. mojavensis I4 showed the highest production of xylanaes $(6.58$ $\mathrm{U} / \mathrm{ml}$ ), followed by fungi isolates which the level of production is of the order of $4 \mathrm{U} / \mathrm{ml}$. The ability of Aspergillus sp. to secrete high concentration of xylanase has been reported (Sohail et al. 2009) and Aspergillus niger was commonly classified as strong xylanase producer (Ibrahim 2008). In addition, isolate I4 produced the high level of pectinase $(4.24 \mathrm{U} / \mathrm{ml})$ in wheat bran, as shown in Table 2. The result observed for isolate $B$. mojavensis I4 suggests this microorganism as one of the major xylanase and pectinase producers. Few reports described the production and characterization of xylanase produced by the same strain (Akhavan Sepahy et al. 2011; Haddar et al. 2012). Janani et al. (2011) showed that maximum production of pectinase was obtained from Bacillus species. The enzymatic activity of $\alpha$-amylase yielded isolates M1 $(2.85 \mathrm{U} / \mathrm{ml}), \mathrm{SE}(4.59 \mathrm{U} / \mathrm{ml})$ and $\mathrm{I} 4(2.38 \mathrm{U} / \mathrm{ml})$. These isolates show low levels of mannanase activity. The wheat bran substrate used in fermentation showed differences in enzyme production. Wheat bran has larger amounts of macro and micronutrients than other agro-industrial by-products, such as sugarcane bagasse, rice straw, wheat straw and rice bran. Wheat bran consists of a complex medium rich in protein, carbohydrates, minerals, lipids and vitamins, which are easily assimilated by microorganisms (Haque et al. 2002). In this concern, use of agricultural residues for the production of xylanase and pectinase has been reported by several workers (Azeri et al. 2010; Cui et al. 2009). The use of agro-industrial by-products, such as wheat bran in fermentation to produce cellulolytic and hemicellulolytic enzymes may represent an alternative to reduce production costs and the environmental impacts caused by these wastes, which can be used for several applications from protein enrichment to bioremediation (Pandey et al. 2000).

\section{Activity staining of extracellular xylanase, pectinase, mannanase and $\alpha$-amylase produced by selected isolates}

The co-production of extracellular xylanase, pectinase, mannanase and $\alpha$-amylase by each selected strain was achieved in the presence of wheat bran as carbon source. In this study, zymography, a sensitive and rapid assay method, was first used for analyzing enzyme activity and to obtain more information on the diversity of the extracellular enzyme secreted by the strain. Xylanolytic activity of the crude enzyme was studied by xylan-zymography. As shown in Fig. 1a, B. mojavensis 4 crude preparation showed a single band of xylanase activity, suggesting the presence of one xylanase in the crude enzyme. Two xylanases were observed in the xylanolytic activity profile of the cell free enzymatic preparation of $B$. mojavensis A21 grown on barley bran medium (Haddar et al. 2012). The zymogram of Aspergillus species revealed the presence of a single band of xylanase activity for A. fumigatus $\mathrm{M} 1$ and $A$. sydowii SE, suggesting the presence of at least one xylanase. Pectinase activity was also evaluated using zymogram activity staining. As shown in Fig. 1b, Aspergillus strain M1 and B. mojavensis I4 secreted at least two pectinases but a unique clear band of pectic hydrolysis was observed in the gel for $A$. sydowii SE crude enzyme indicating the presence of one pectinase with a low molecular weight. Despite a lower level of mannanase activity in the culture medium of different isolates, this activity was easily revealed by mannanzymography. The results showed only one band of mannanolytic activity, suggesting the presence of at least one mannanase activity (Fig. 1c). The extracellular enzyme system of $B$. licheniformis SVD1 displayed a variety of enzyme activities and based on zymogram analysis there were two endoglucanases, seven xylanases, two mannanases and one pectinase in the multi-enzyme complex of this strain (van Dyk et al. 2010). Starch-zymogram analysis of crude enzyme of the Aspergillus species showed the same profile of enzyme production and indicated the presence of at least three $\alpha$-amylases with different molecular weights (Fig. 1d). B. mojavensis I4 showed only one band of amylolytic activity, signifying the existence of at least one $\alpha$ amylase activity. Hmidet et al. (2009) showed that the enzyme preparation of $B$. licheniformis $\mathrm{NH} 1$, 
cultivated in medium containing only chicken feathers as carbon source, showed one amylolytic activity using zymography technique. The production of a single amylolytic activity was reported earlier (Burhan et al. 2003; Deutch, 2002).
Additionally, multiple $\alpha$-amylase production has also been reported from many Bacillus strains. Najafi and Deobagkar (2005) reported the production of three $\alpha$-amylases by $B$. subtilis AX20. (a)

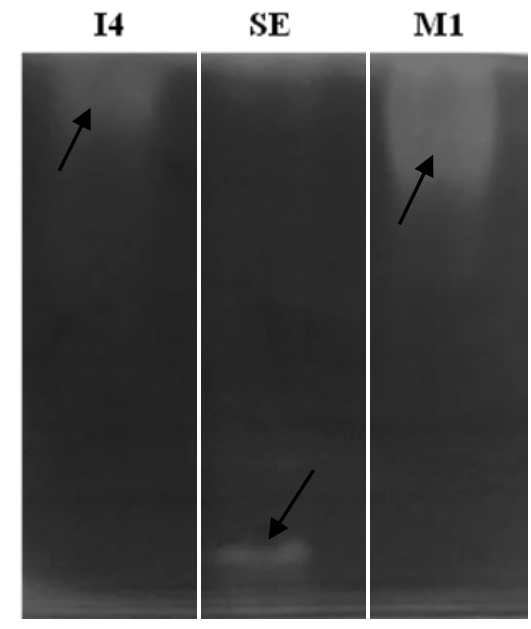

(C)

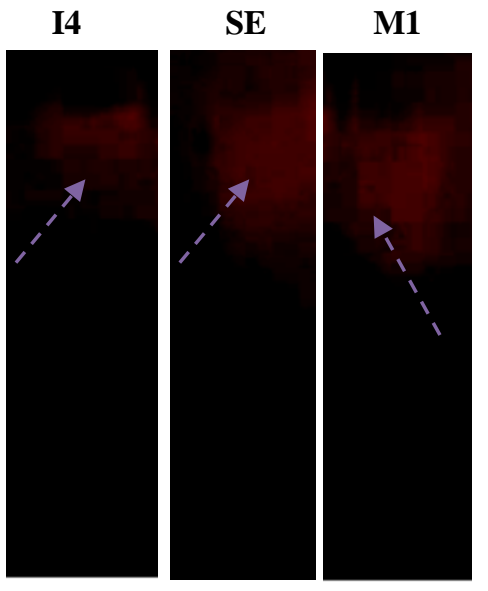

(b)

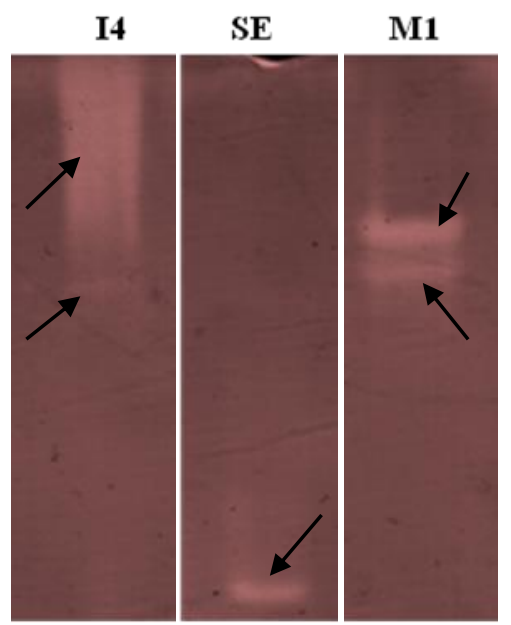

(d)

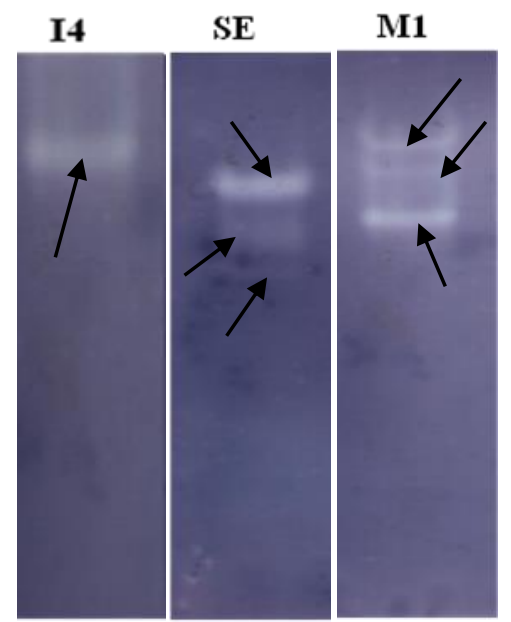

Figure 1. Zymogram activity staining showing xylanolytic (a), pectinolytic (b), mannanolytic (c) and amylolytic (d) activities of the crude enzyme of selected isolates cultivated in wheat bran.

pH and temperature optima determination for various enzymes of selected isolates

The $\mathrm{pH}$ and temperature optima for xylanolytic, pectinolytic, mannanolytic and amylolytic activities are displayed in Table 3. I4 xylanase exhibited optimum activity at $\mathrm{pH} 5.0$ and $55^{\circ} \mathrm{C}$ and
I4 mannanase was active at $\mathrm{pH} 5.0$ and $65^{\circ} \mathrm{C}$. In contrast, xylanases secreted by B. mojavensis A21 (Haddar et al. 2012) and B. mojavensis AG137 (Akhavan Sepahy et al. 2011) (39) were more active at high $\mathrm{pH}$ values and at temperature of $50-55^{\circ} \mathrm{C} . \alpha-$ amylase activity remained relatively constant 
between $\mathrm{pH} 5.0$ and 8.0 and had an optimum at $65-$ $75^{\circ} \mathrm{C}$. Similar $\mathrm{pH}$ optima of 6.0-6.5 and 5.0-7.0 have been reported for $\alpha$-amylases from $B$. licheniformis 44MB82-A (Ivanova et al. 1993) and B. licheniformis NRRL B14368 (Bose and Das 1996), respectively. Alkali-activity and stability of pectinases are very important properties due to their potential applications in several industrial processes. B. mojavensis $\mathrm{I} 4$ is a good producer of alkaline pectinase. Indeed, the optimum $\mathrm{pH}$ of pectinase activity displayed a peak at $\mathrm{pH} 8.0$ and $60^{\circ} \mathrm{C}$.

Optimum $\mathrm{pH}$ and temperature for xylanase, pectinase, mannanase and $\alpha$-amylase of Aspergillus species were $4.0-5.5$ and $50-65^{\circ} \mathrm{C}$, respectively. These characteristics were similar to other previous report (Fang et al. 2008; Sahnoun et al. 2012; Sandri et al. 2013; Squina et al. 2009). Ang et al. (2013) reported that the optimum $\mathrm{pH}$ of xylanase produced by A. fumigatus $\mathrm{SK} 1$ was $\mathrm{pH} 4.0$. These findings are in line with earlier reports showing that optimal culture $\mathrm{pH}$ of xylanase for A. funigatus $\mathrm{Z} 5$ was between pH 3.0 to pH 6.0 (Liu et al. 2011). The optima $\mathrm{pH}$ and temperature for pectinase activity of A. niger were $\mathrm{pH} 6.0$ and $60^{\circ} \mathrm{C}$, respectively (Oyeleke et al. 2012).

\section{Identification and phylogenetic analysis of selected isolates}

Fungus-specific primers were used to amplify the 18S rDNA gene and the ITS region for the M1 and $\mathrm{SE}$ isolates. Moreover, the $16 \mathrm{~S}$ rDNA gene primers were used for the I4 bacterial isolates. PCR products were analyzed on agarose gel electrophoresis. The estimated length of the amplified 18S and ITS rDNA fragments were approximately 1800 and $600 \mathrm{bp}$. For the I4 isolates, the estimated length of the amplified 16S rDNA fragment was $1500 \mathrm{bp}$.

For isolates identification, the corresponding 18S/ITS or 16S rDNA PCR product sequence was analyzed by blast against the nr nucleotide database on NCBI. BLAST results were attended with phylogenetic analysis. Indeed, multiple alignment and phylogenetic tree showed that M1 and SE strains are Aspergillus fumigatus and Aspergillus sydowii, respectively (Fig. 2b). The bacterial isolate I4 belonged to the genus of Bacillus and showed closest relationship with Bacillus mojavensis (Fig. 2a). The $18 \mathrm{~S}$ rDNA gene sequences of M1 and SE strains and the 16S rDNA gene sequence for I4 strain have been submitted to GenBank database and assigned accession numbers KF322139, KF322140 and KF012872 respectively. 
a

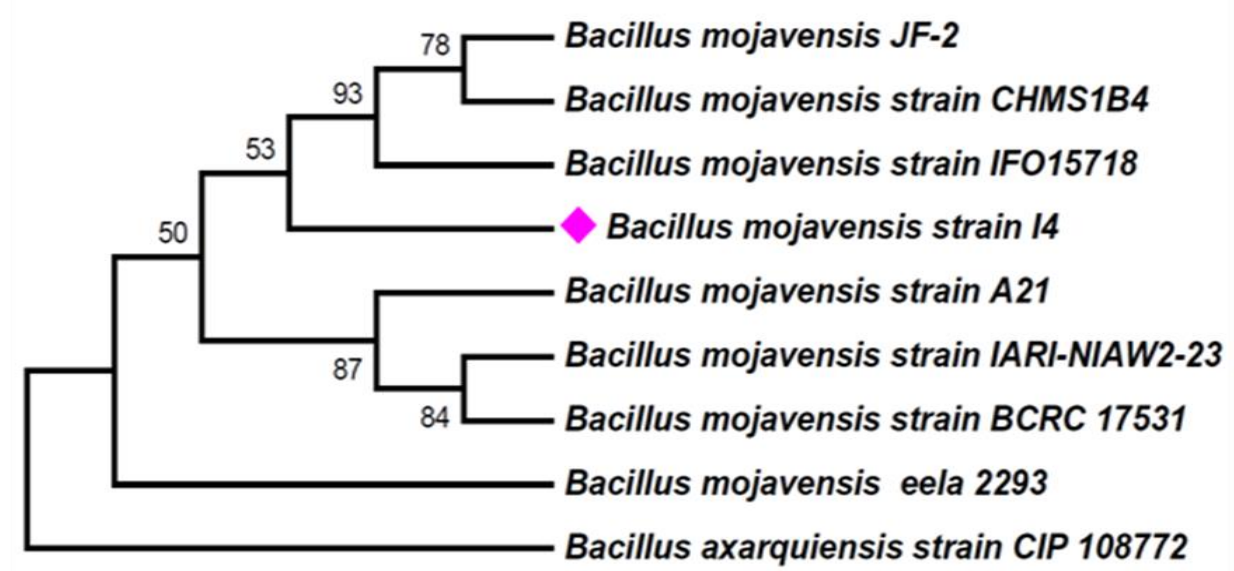

b

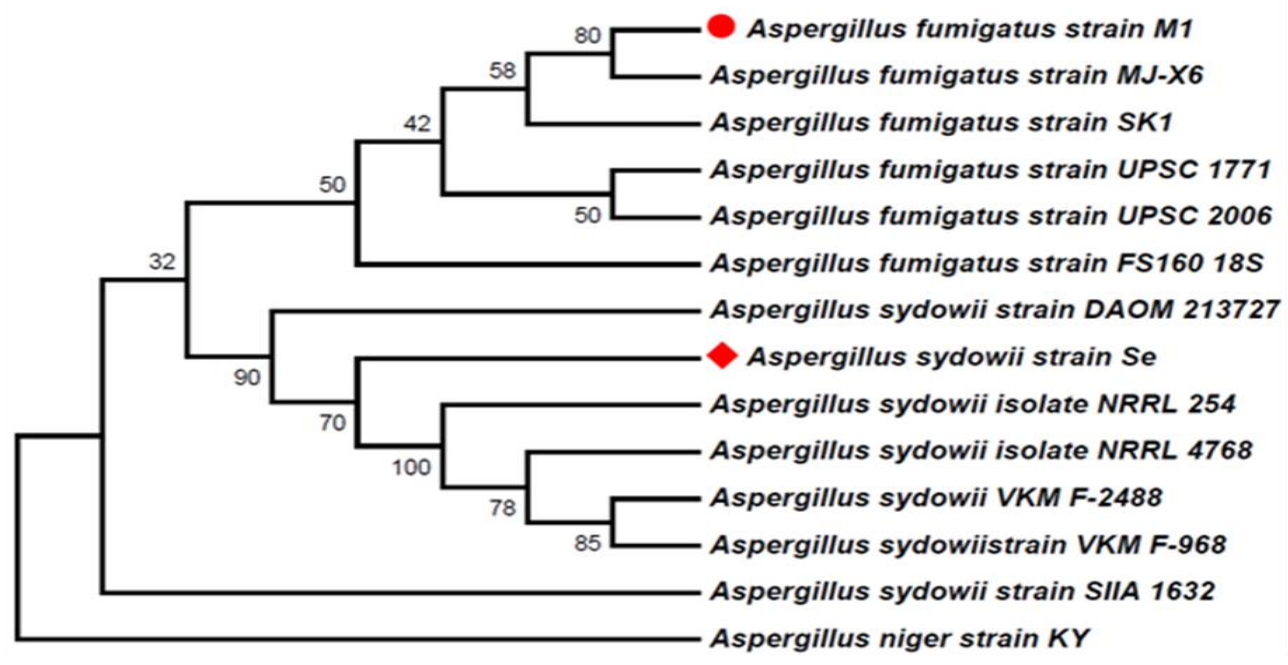

Figure. 2. Phylogenetic tree based on a comparison 16S rDNA sequences (a) for Bacillus mojavensis strains and the 18S rDNA sequences (b) for Aspergillus fumigatus and Aspergillus sydowii. The branching pattern was generated by the neighbor-joining method. The numbers at the nodes indicate the levels of bootstrap support based on a neighborjoining analysis of 1,000 replicates. Genebank accession numbers for the strains used in the tree construction are: strain F1 (JF901760.1); A21 (EU366229.1), XH1 (JF523538.1), I4 (KF012872.1), strain BCRC (EF433405.1), JF2(AY436360.1), XA1-8 (JF496257.1) and 26-4 (HM104641.1). Aspergillus fumigatus: strain MJ-X6 (HM590663.1), train SK1 (JQ665711.1), strain FS160 (FJ840490.1), strain UPSC 1771 (AF548061.1), strain UPSC 2006 (AF548062.1). Aspergillus sydowii : strain DAOM 213727 (JN938975.1) and for Aspergillus versicolor : strain PSFNRO-2 (HQ393875.1), strain HDJZ-ZWM-16 (GU227343.1), strain DAOM 222010 (JN938969.1), strain NRRL $238(\mathrm{AB} 002064.1)$.

\section{CONCLUSION}

In conclusion, homology analysis of the $16 \mathrm{~S}$ gene for bacteria and $18 \mathrm{~S}$ gene for fungal strains provides suitable phenotypic data that can be used to determine both close and very distant relationships. In the present study, this approach has allowed the identification of industrially important xylano-pectinolytic producing organisms, I4, SE and M1. The closest phylogenetic neighbors according to the $16 \mathrm{~S}$ gene sequence data for the isolate I4 was Bacillus mojavensis. According to the $18 \mathrm{~S}$ gene sequences, SE strain was identified as Aspergillus sydowii and M1 strain was Aspergillus 
fumigatus. The results indicated that all isolates were able to produce xylanase when $1 \%$ wheat bran was added as carbon source and isolate I4 have important level of pectinase production.

Further studies on optimization of xylanase and pectinase production by using natural lignocellulosic substrates, purification and characterization of xylanase and pectinase by potential strains are in progress.

\section{ACKNOWLEDGEMENT}

This work was funded by the Ministry of Higher Education and Scientific Research-Tunisia.

\section{REFERENCES}

Abe JI, Bergmann F, Obata K, Hizukuri S. Production of the raw-starch digesting amylase of Aspergillus sp. K-27. Appl Microbiol Biotechnol. 1988; 27: 447-450.

Ang SK, Shaza EM, Adibah YA, Suraini AA, Madihah MS. Production of cellulases and xylanase by Aspergillus fumigatus SK1 using untreated oil palm trunk through solid state fermentation. Process Biochem. 2013; 48: 1293-1302.

Akhavan Sepahy A, Ghazi S, Akhavan Sepahy M. Costeffective production and optimization of alkaline xylanase by indigenous Bacillus mojavensis AG137 fermented on agricultural waste. Enz Res. 2011; 2011: 593624.

Azeri C, Tamer AU, Oskay M. Thermoactive cellulasefree xylanase production from alkaliphilic Bacillus strains using various agro-residues and their potential in biobleaching of kraft pulp. Afr J Biotechnol. 2010; 9: 63-72.

Bailey MJ, Biely P, Poutanen K. Interlaboratory testing of methods for assay of xylanase activity. J Biotechnol. 1992; 23: 257-270.

Bose K, Das DT. Thermostable alpha-amylase production using Bacillus licheniformis NRRL B14368. Indian J Exp Biol. 1996; 34: 1279-1282.

Bradford MM. A rapid and sensitive method for the quantitation of microgram quantities of protein utilizing the principle of protein-dye binding. Anal Biochem. 1976; 72: 248-254.

Butt MS, Nadeem MT, Ahmad Z, Sultan MT. Xylanases in Baking Industry. Food Technol Biotech. 2008; 46: 22-31.

Burhan A, Nisa U, Gokhan C, Omer C, Ashabil A et al, Enzymatic properties of a novel thermostable, thermophilic, alkaline and chelator resistant amylase from an alkaliphilic Bacillus sp isolate ANT-6, Process Biochem, 38 (2003) 1397-1403.

Christakopoulos P, Katapodis P, Kalogeris E, Kekos D, Macris BJ, et al. Antimicrobial activity of acidic xylo-oligosaccharides produced by family 10 and 11 endoxylanases. Int J Biol Macromol. 2003; 31: 171175.

Cui FJ, Li Y, Liu ZQ, Zhao H, Ping LF et al. Optimization of fermentation conditions for production of xylanase by a newly isolated strain, Penicillium thiersii ZH-19. World J Microbiol Biotechnol. 2009; 25: 721-725.

Dalvi P, Anthappan P. Amylase and pectinase from single source for simultaneous desizing and scouring. Ind J Fiber Text Res. 2007; 32: 459-465.

Deutch CE. Characterization of a salt-tolerant extracellular a-amylase from Bacillus dipsosauri. Lett Appl Microbiol. 2002;

35:78-84.

Dubois M, Gilles KA, Hamilton JK, Rebers PA, Smith F. Colorimetric method for determination of sugars and related substances. Anal Chem. 1956; 28: 350356.

Fang HY, Chang SM, Lan CH, Fang TJ. Purification and characterization of a xylanase from Aspergillus carneus M34 and its potential use in photoprotectant preparation. Process Biochem. 2008; 43: 49-55.

Gessesse A, Gashe BA. Production of alkaline xylanase by an alkaliphilic Bacillus sp. isolated from an alkaline soda lake. J Appl Microbiol. 1997; 83: 402406.

Gupta VK, Gaur R, Yadava SK, Darmwal NS. Optimization of xylanase production from free and immobilized cells of Fusarium Solani F7. Biores. 2009; 4: 932-945.

Haddar A, Driss D, Frikha F, Ellouz-Chaabouni S, Nasri M. Alkaline xylanases from Bacillus mojavensis A21: production and generation of xylooligosaccharides. Int J Biol Macromol. 2012; 51: 647-656.

Haque MA, Shams-Ud-Din M, Haque A. The effect of aqueous extracted wheat bran on the baking quality of biscui. Int J Food Sci Technol. 2002; 37: 453-462.

Hmidet N, El-Hadj Ali N, Haddar A, Kanoun S, SellamiKamoun A. Alkaline proteases and thermostable $\alpha$ amylase co-produced by Bacillus licheniformis NH1: Characterization and potential application as detergent additive. Biochem Eng J. 2009; 47: 71-79.

Hoondal GS, Tiwari RP, Tewari R, Dahiya N, Beg QK. Microbial alkaline pectinases and their industrial applications: a review. Appl Microbiol Biot. 2002; 59: 409-418.

Ibrahim C O, Development of applications of industrial enzymes from Malaysian indigenous microbial sources, Bioresour Technol, 99 (2008) 4572-4582.

Ivanova VN, Dobreva EP, Emanuilova EI. Purification and characterization of a thermostable alpha-amylase from Bacillus licheniformis. J Biotechnol. 1993; 28: 277-289.

Janani L, Karthik G, Kumar KV, Rao B. Screening of pectinase producing microorganisms from agricultural waste dump soil. Asian J Biochem Pharm Res. 2011; 2: 2231-2560. 
Kumar V, Satyanarayana T. Thermo-alkali-stable xylanase of a novel polyextremophilic Bacillus halodurans TSEV1 and its application in biobleaching. Int Biodeterior Biodegrad. 2012; 75 : 138-145.

Laemmli UK. Cleavage of structural proteins during the assembly of the head of bacteriophage T4. Nature. 1970; 227: 680-685.

Liu DY, Zhang RF, Yang XM, Xu YC, Tang Z et al. Expression, purification and characterization of two thermostable endoglucanases cloned from a lignocellulosic decomposing fungi Aspergillus fumigatus Z5 isolated from compost. Protein Expression Purif. 2011; 79: 176-186.

Malvessi E, Silveira MMd. Influence of medium composition and $\mathrm{pH}$ on the production of polygalacturonases by Aspergillus oryzae. Braz Arch Biol Technol. 2004; 47: 693-702.

Mandels M, Andreotti R, Roche C. Measurement of saccharifying cellulase. Biotechnol Bioeng Symp. 1976; 6: 21-33.

Mellon J E \& Cotty P J, Expression of pectinase activity among Aspergillus flavus isolates from southwestern and southeastern United States, Mycopathologia, 157 (2004) 333-338.

Miller GL. Use of dinitrosalicylica acid reagent for determination of reducing sugar. Anal Chem. 1959; 31: 426-428.

Miller JH. Experiments in molecular genetics, Cold Spring Harbor Laboratory Press, Cold Spring Harbor, NY. 1972; 431-435.

Moreira LRS, Filho EXF. An overview of mannan structure and mannan-degrading enzyme systems., Appl Microbiol Biotechnol. 2008; 79: 165-178.

Nair SG, Sindhu R, Shashidhar S. Fungal xylanase production under solid state and submerged fermentation conditions. Afr J Microbiol Res. 2008; 2: 82-86.

Najafi MF, Deobagkar D. Purification and characterization of an extracellular alpha-amylase from Bacillus subtilis AX20. Protein Expr Purif. 2005; 41: 349-354.

Ortega N, de Diego S, Perez-Mateos M, Busto MD. Kinetic properties and thermal behaviour of polygalacturonase used in fruit juice clarification. Food Chem. 2004; 88: 209-217.

Oyeleke SB, Oyewole OA, Egwim EC, Dauda BEN, Ibeh EN. Cellulase and pectinase production potentials of Aspergillus niger isolated from corn cob. Bayero J Pure App Sci. 2012; 5: 78-83.

Oyewole OA, Oyeleke SB, Dauda BEN, Emiade S. Production of amylase and protease enzymes by Aspergillus niger and Penicillium frequenstans isolated from abattoir effluent. Microbiol J. 2011; 1: 174-180.

Pandey A, Soccol CR, Mitchell D. New developments in solid state fermentation: I-bioprocesses and products, Process Biochem. 2000;35: 1153-1169.
Phutela U, Dhuna V, Sandhu S, Chadha BS. Pectinase and polygalacturonase production by a thermophilic Aspergillus fumigatus isolated from decomposting orange peels. Braz J Microbiol. 2005; 36: 63-69.

Ricard M, Reid ID. Purified pectinase lowers cationic demand in peroxide-bleached mechanical pulp. Enz Microbial Technol. 2004; 34: 499-504.

Sahnoun M, Bejar S, Sayari A, Triki MA, Kriaa M et al. Production, purification and characterization of two $\alpha$-amylase isoforms from a newly isolated Aspergillus Oryzae strain S2. Process Biochem. 2012; 47: 18-25.

Schallmey M, Singh A, Ward OP. Developments in the use of Bacillus species for industrial production. Can J Microbiol. 2004; 50: 1-17.

Sandri IG, Lorenzoni CMT, Fontana RC, da Silveira MM. Use of pectinases produced by a new strain of Aspergillus niger for the enzymatic treatment of apple and blueberry juice, LWT Food Sci Technol. 2013; 51: 469-475.

Squina FM, Mort AJ, Decker SR, Prade RA. Xylan decomposition by Aspergillus clavatus endoxylanase. Protein Expression Purifi. 2009; 68: 65-71.

Sohail M, Naseeb S, Sherwani SK, Sultana S, Aftab S et al. Distribution of hydrolytic enzymes among native fungi: Aspergillus the pre-dominant genus of hydrolase producer. Pak J Bot. 2009; 41: 2567-2582.

Tamura K, Peterson D, Peterson N, Stecher G, Nei M et al, MEGA5: Molecular evolutionary genetics analysis using maximum likelihood, evolutionary distance, and maximum parsimonym Methods. Mol Biol Evol, 28 (2011) 2731-2739.

Tseng YH, Fang TJ, Tseng SM. Isolation and characterization of a novel phytase from Penicillium simplicissimum. Folia Microbiol. 2000; 45: 121-127.

van Dyk J S, Sakka M Sakka K, Pletschke BI. Identification of endoglucanases, xylanases, pectinases and mannanases in the multi-enzyme complex of Bacillus licheniformis SVD1, Enz Microbial Technol. 2010; 47: 112-118.

Verweij PE, Meis JFGM, van den Hurk P, Zoll J, Samson RA et al. Phylogenetic relationships of five species of Aspergillus and related taxa as deduced by comparison of sequences of small subunit ribosomal RNA. Med Mycol. 1995; 33: 185-190.

Viikari L, Suurnäkki A, Grönqvist S Raaska L, Ragauskas A. Forest Products: Biotechnology in Pulp and Paper Processing, in: S. Editor-inChief: Moselio (Ed.) Encyclopedia of Microbiology (Third Edition), Academic Press, Oxford. 2009; 8094.Waeonukul R, Kyu KL, Ratanakhanokchai K. Multiple cellulases and xylanases from Bacillus circulans B6 during growth on avicel under aerobic condition. Thai J Biotechol. 2007: 8: 27-32.

Virk, A. P., Puri, M., Gupta, V., Capalash, N., \& Sharma, P. Combined enzymatic and physical deinking methodology for efficient eco-friendly recycling of old newsprint. PLoS ONE,2013; 8(8), 1-8 
White TnJ, Bruns T, Lee S \& Taylor J W, Amplification and direct sequencing of fungal ribosomal RNA genes for phylogenetics In: Innis MA, Gelfand DH, Sninsky JJ, White TJ, editors, PCR meth appl. San Diego: Academic Press, (1990) 315-322.

Wilkins MR, Widmer WW, Grohmann K, Cameron RG. Hydrolysis of grapefruit peel waste with cellulase and pectinase enzymes. Bioresour Technol. 2007; 98: 1596-1601.

Yasinok AE, Sahin FL, Haberal M. Isolation of endophytic and xylanolytic Bacillus pumilus strains from zea mays, J Appl Sci, 2008; 14: 374-380.
Zahura UA, Rahman MM, Inoue A, Tanaka H, Ojima T. An endo-beta-1,4-mannanase, AkMan, from the common sea hare Aplysia kurodai, Comp Biochem Physiol B Biochem Mol Biol. 2010; 157: 137-143.

Zhang M, Su R, Qi W, He Z. Enhanced enzymatic hydrolysis of lignocellulose by optimizing enzyme complexes. Appl Biochem Biotechnol. 2010; 160: 1407-1414.

Received: March 07, 2016; Accepted: April 26, 2016 